\title{
'EPISTEMOLOGY': FOR POLICY ANALYSTS AND POLICY DEVELOPMENT IN HEALTHCARE MANAGEMENT
}

\author{
Bobby Thomas Cameron MA, BA (Hons), CAPM \\ Policy Coordinator, Health PEI - Prince Edward Island, Canada \\ btr.cameron@gmail.com
}

\section{ABSTRACT}

A person's outlook on research is important to understand when teams are developing healthcare policies and clinical standards. Often there are conflicts as physicians, healthcare workers, analysts and others bring unique knowledge systems together. Epistemology, the possible ways of gaining knowledge of social realities, is a term which policy analysts can better understand to support the policy development process.

\section{Indexing terms/Key Words}

policy; organization \& administration; decision making; knowledge.

\section{Council for Innovative Research}

Peer Review Research Publishing System

\section{Journal: JOURNAL OF SOCIAL SCIENCE RESEARCH}

Vol 7, No. 2

www.jssronline.com, editor@jssronline.com 


\section{INTRODUCTION}

The management and delivery of healthcare services ultimately involves the creation of policies which are based on research and ideally informed by the appropriate stakeholders. This process often involves coming to a consensus with individuals from across the healthcare system to develop appropriate and responsive solutions to complex problems. Since at least the 1980s, researchers have been writing about differences in the conceptualization of common terms and the use of knowledge in health care settings (Mizrahi \& Abramson, 1985). Indeed while physicians, nurses, analysts, planners, and others collaborate successfully on a daily basis, the scientific mode of inquiry - and its focus on empiricism often dominates other forms of knowledge creation and validation and can make sometimes seemingly straight forward decision-making a challenge.

At the organizational level operational decisions are often influenced by formal rationality whereas studies of clinical practice suggest that evidence for patient-related decisions is highly influenced by personal experience, the opinions of subject matter experts, and anecdotal evidence (Green, 2000). Hence, many individuals whom have been trained in the "hard sciences" do indeed rely on impressionistic data to inform decision-making in certain cases over others. Undoubtedly there is a wide range of factors which impact how people make decisions in the healthcare system.

This article asserts that those leading the development of management policies such as policy analysts, managers, chairs, and coordinators can benefit from understanding the term 'epistemology' and its relatives in order to improve productivity when working with diverse policy teams and other knowledge-generators. Knowing more about the almost innate orientations people have towards research and knowledge creation will help in seeing eye-to-eye throughout the policy development process and in valuing diversity in perspectives as a strength. This article provides a starting point for a discussion of epistemology in the healthcare management setting.

\section{DISCUSSION}

Epistemology faces conceptual disunity in the literature and is often used in different ways. Williams (2000: 1) in Problems of Knowledge: A Critical Introduction to Epistemology defines the term quite broadly as the branch of philosophy that concerns itself with human knowledge. Grix (2002: 177) provides a more tangible definition and states that epistemology is "the possible ways of gaining knowledge of social reality, whatever it is understood to be. In short, claims about how what is assumed to exist can be known." Also important is how Delanty and Strydom (2003: 5) note that there is an ongoing debate about whether there is a distinction between knowledge and opinion.

Closely related to epistemology are the terms positivism and non-positivism. Reality in the positivist tradition is believed to be 'fixed'. In other words, as stated by Dewey "the facts are out there and only need to be observed, assembled and arranged to give rise to suitable and grounded generalizations" (Delanty \& Strydom, 2003: 282). Generally speaking, in the positivist tradition researchers do not emphasize the way in which their values impact the selection of evidence. Positivism, assumes "a value free social science" (Delanty \& Strydom, 2003: 216) or that reality is fixed entirely without the subjective interpretation of the researcher and is able to be truly discovered. It is a "position that asserts that social phenomena and their meanings have an existence that is independent of social actors" (Grix, 2002: 177).

Non-positivism on the other hand recognizes the subjectivity of reality. It "asserts that social phenomena and their meanings are continually being accomplished by social actors. It implies that social phenomena and categories are not only produced through social interaction but that they are in a constant state of revision" (Grix, 2002). This position breaks from the positivist tradition. However, it does not imply necessarily that no reality exists, rather, it takes into account that what reality means for one individual or group changes depending on their perspective, positionality, bias and reflexivity (University of Strathclyde, n.d.). One can come close to articulating reality and what exists, but can never entirely because reality is entirely a social construction, and thus 'social construction' is an approach in and of itself. 


\section{IMPLICATIONS FOR HEALTHCARE MANAGEMENT}

As we come to working groups, teams, and other meetings and are tasked with creating a policy to remedy a problem which has been identified, often on the "front-line", it is important to recognize the diversity of epistemological perspectives which we are inevitably going to encounter. Often times persons occupying healthcare professions such as physicians, specialists, nurse practitioners, laboratory staff, and others have received formal training through university programs which relied heavily on positivist research. Furthermore, the research which is referenced in medical journals in particular is often fixed on "hard data" and authors are focused on discovering general laws among phenomenon (Alderson, 1998).

However, the healthcare system is populated with a broad range of epistemological perspectives. Each person's epistemological beliefs are as unique as a finger print and should be valued as such. For many policy analysts, program evaluators, managers, and other administrators coming from the arts, liberal arts, and humanities, non-positivist qualification - including the interpretive approaches - are considered to be valid forms of knowledge and evidence. Furthermore, and more importantly, often times we find a strong orientation towards the possibility of the existence of "multiple truths". Non-positivism, although not exclusive to the positions mentioned here, is an orientation to knowledge which often places meaning-making practices; language; texts; and personal experiences at the forefront. Therefore, among the various groups across the healthcare system there are frequently lines drawn between that which is - and can be - evidence-based (often positivist) and evidence-informed (often non-positivist) (Lomas \& Brown, 2009).

Without a doubt, this typography of healthcare professions and correlating philosophical orientations is in no way conclusive and is indeed a generalization. The purpose here is to bring our attention to the fact that healthcare management is possibly unique in that solutions to problems regularly require the merger of professionals who come from very divergent epistemological positions. Based on this discussion, the following key terms have been identified as important to understand when participating in healthcare management policy development processes:

(1) Epistemology - the possible ways of gaining knowledge of social reality, whatever it is understood to be. Claims about how what is assumed to exist can be known (Grix, 2002:177).

(2) Positivism - Positivism aims to discover general laws about relations between phenomena, particularly cause and effect. Experiments are designed to measure and explain associations and to test whether a law can be disproved. ${ }^{1}$ Decisions are made on the statistical study of past events (Green, 2000).

(3) Non-positivism - asserts that there is not a single view or truth, and that a range of views can be valid in different ways (Alderson, 1998).

(4) Perspective - refers to the context which influences what a person can see and how they interpret it. It may indicate ideology or value systems (e.g. feminist, socialist, anti-racist, post-colonial and queer research) (University of Strathclyde, n.d.).

(5) Positionality - indicates the social and political landscape inhabited by a person (e.g. gender, nationality, race, religion, sexuality, (dis)abilities, social class and social status) (University of Strathclyde, n.d.).

(6) Reflexivity - an explicit self-consciousness about one's social, political and value positions in relation to how these might have influenced the design, execution and interpretation of theory, data and conclusions (University of Strathclyde, n.d.).

\section{CONCLUSION}

This brief article has asked policy teams, working groups, and others involved in decision making processes across the healthcare system to consider the myriad of epistemological positions from all points on the philosophical spectrum. From specialists, physicians, and nurses to policy analysts, business planners, and program evaluators, the healthcare system 
is comprised of a wide range of professionals, many of whom come from divergent philosophical backgrounds. Through understanding these differences we can not only mitigate conflicts, but learn how to approach and capitalize upon our differences in order to better manage the healthcare system as a whole.

\section{REFERENCES}

[1] Alderson, P. (1998). The importance of theories in health care. British Medical Journal 317, 1007-1010.

[2] Delanty, G. and P. Strydom. (2003). Philosophies of social science: the classic and contemporary readings. Maidenhead: Open University Press, p.5.

[3] Green, J. (2000). Epistemology, evidence and experience: evidence based healthcare in the work of accident alliances. Sociology of Health \& IIIness 22 (4), p.455.

[4] Grix, J. (2002). Introducing students to the generic terminology of social research. Politics 22 (3), p.177.

[5] Mizrahi, T. \& Abramson, J. (1985). Sources of strain between physicians and social workers: implications for social workers in health care settings. Social Work in Healthcare 10 (3), 33-51.

[6] Williams, M. (2001). Problems of Knowledge: A Critical Introduction to Epistemology. Oxford: Oxford University Press, p.1.

[7] University of Strathclyde. Perspective, Positionality, Bias and Reflexivity. Scotland, UK. Retrieved from http://tinyurl.com/arfsmt8

\section{Author's biography}

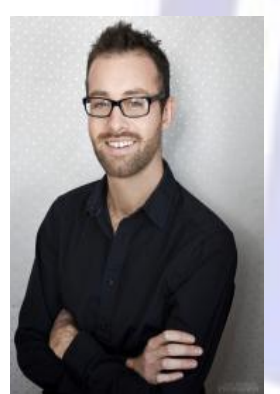

Bobby Thomas Cameron received his Master of Arts degree in Public Policy and Administration from Ryerson University (Toronto) and his Bachelor of Arts degree in History (Honours) and Political Studies from the University of Prince Edward Island (Charlottetown). He is currently working at the intersection of policy and healthcare administration. His website is here: www.bobbycameron.net. 